\title{
Transitivity System in Different Spoken Discourses
}

\author{
Indah Sari \\ Universitas Panca Budi, Medan, North Sumatera \\ Rosdiana Sembiring \\ STBA-PIA, Medan, North Sumatera
}

\begin{abstract}
The aim of this study was to describe the types of processes in transitivity systems used in various spoken discourses and the reasons of using them. This research applied descriptive qualitative design which relies on words to describe the phenomena. The documentation technique was used to achieve the aim of the study. The sources of the data were speech entitled of I Have a Dream by Marthin Luther King published in 1963; the sermon on the mount by Jesus of Nazareth published in 2012; and the song entitled of You Raise Me Up by Josh Groban in 2003. The findings showed that there were six types of processes in speech and sermon but not all types of them were used in the song. The types of processes found in the speech were 139 processes; dominantly was material process which was $60(43 \%)$. There were 76 processes in sermon, and dominantly were $44(57,8 \%)$ material process; while there were 42 processes in the song; dominantly was $25(59,6 \%)$ material process. There were 6 reasons of using types of processes in different spoken discourses: 1) physical actions, 2) thinking actions, 3) identifying features, 4) speaking actions, 5) physiological actions and 6) actions that signal the existence of something/someone. It could be concluded that material process are found to be the most dominant in spoken discourse as it represents the process of doing.
\end{abstract}

Keywords: transitivity, process, spoken discourse

\section{Introduction}

Systemic Functional Linguistics is a theory about language as a resource for making meaning which is situated in a context of situation and a context of culture. This theory also stresses on communication. In other words, it concerns with the relation between language and context in which it is used. It is known as meta-function. Saragih (2010:1) stated that meta-functions consists of 3 functions, namely; (1) Interpersonal function, (2) Ideational function, and (3) Textual function. First, Interpersonal function means that language is used to interact with others. Second, Ideational function means that the language is used to organize, to understand and to express our perceptions of the world and consciousness. Ideational function are divided into two, they are experiential function, where language is used to express experience, and logical function is encoded in the 
grammar as complex unit in which the clauses should be related each other and can take conclusion logically based on the clauses described in the text. Third, Textual function means that the language is used to organize experience. As with the clause as exchange, there is one major system of grammatical choice involved in this kind of meaning, this is the system of transitivity or process type.

Some of the studies about transitivity were conducted especially in relation to the spoken discourse. One of them was Harwiyati (2016) who found that all types of transitivity processes appeared in Joko Widodo's Speech and relational process was dominantly used in the utterances. Hemas and Ariyanti (2016) found that Emma Watson dominantly used mental process followed by material process in her speech. The underlying reason of its use was because she wanted to influence people to have more correct views of feminist movement. These processes were used to get the listeners' sympathy by showing her emotion, thinking, and inclination. These researches were just focused on the spoken discourse such as speech. Meanwhile, spoken discourse was also varied in forms such as speech, sermon, songs, etc. Therefore, a study in relation to these various forms of spoken discourse needs to be conducted in order to get a wider horizon of how the transitivity of processes works in these forms.

\section{Method}

This research applied descriptive qualitative design which focused on words rather than numbers. In some cases, numbers are used to indicate the frequency of each category in transcripts or the extent to which a form of action occurs. This study was conducted with the aim of analyzing the use of processes in transitivity system in different spoken discourses through speech, sermon, and song.

The source of the data was speech entitled of I Have a Dream by Martin Luther King in 1963; the sermon of the mount by Jesus of Nazareth which published in 2012. This sermon was a collection of sayings and teachings of Jesus of Nazareth, which emphasized his moral teaching found in the Gospel of Matthew. It was the first of the Five Discourses of Matthew and took place relatively early in the Ministry of Jesus after he had been baptized by John the Baptist and preached in Galilee; and the song entitled You Raise Me Up by Josh Groban in 2003.

The data was analyzed by following these steps: (1) reading the transcript of the whole data source, (2) dividing the transcript of speech, sermon and song into clauses, (3) 
identifying and classifying the data that belongs to the transitivity system, (4) analyzing the data that belongs to the processes in transitivity system, (5) identifying each spoken discourse's reason in using types of processes in transitivity system, (6) drawing the conclusion.

\section{Result}

\section{Types of Processes in Transitivity System in Different Spoken Discourses}

Theoretically, there are six types of processes in transitivity system proposed by Hallidayin Saragih (2006:03) namely Material process, Mental process, Relational process, Verbal process, Behavioral process, Existential process.

Empirically, all of these types of processes were found in spoken discourses such as speech and sermon. However, there were only material, mental, relational processes were found in the song. The analysis of the processes in different spoken discourses can be seen in this following data:

The speech entitled I Have a Dream by Martin Luther King

\section{Data 1}

\begin{tabular}{|l|l|l|l|}
\hline When & $\begin{array}{l}\text { the architects of our } \\
\text { republic }\end{array}$ & wrote & $\begin{array}{l}\text { the magnificent words of the } \\
\text { Constitution and the Declaration } \\
\text { of Independence }\end{array}$ \\
\hline & P1: Actor & $\begin{array}{l}\text { Pro: } \\
\text { Material }\end{array}$ & P2: Goal \\
\hline
\end{tabular}

The word "wrote" belongs to material process since the word expresses physical action, and it also has two participants namely; the architects of our republic (actor) and the magnificent words of the Constitution and the Declaration of Independence (goal).

\section{Data 2}

\begin{tabular}{|l|l|l|l|}
\hline And & those who & Hope & $\begin{array}{l}\text { that the Negro needed to blow off } \\
\text { steam }\end{array}$ \\
\hline & Senser & Pro: Mental & Phenomenon \\
\hline
\end{tabular}

The word "Hope" belongs to mental process since the word expresses the feeling or the thinking of people, and it also has two participants, namely Those who its mean some people (senser) and that the Negro needed to blow off steam(phenomenon).

\section{Data 3}

\begin{tabular}{|l|l|l|l|}
\hline I & Am & happy to join with you & Today \\
\hline
\end{tabular}




\begin{tabular}{|l|l|l|l|}
\hline Carrier & Pro: Relational & Attribute & Cir: Loc: Temporal \\
\hline
\end{tabular}

The word "am" belongs to relational process since the word assigns a quality of someone feeling, and it also has two participants, namely $I$ (Carrier) and happy to join with you (Attribute).

Data 4

\begin{tabular}{|l|l|l|l|l|}
\hline I & Say & to you & Today & my friends \\
\hline P1: Sayer & Pro: Verbal & P2: Receive & Circumstance & P2: Receive \\
\hline
\end{tabular}

The word "say" belongs to verbal process since the word symbolically signaling that some people is saying, and it also has two participants, namely $I$ (sayer) and to you (Receiver).

\section{Data 5}

\begin{tabular}{|l|l|l|l|}
\hline $\begin{array}{l}\text { One hundred years } \\
\text { later }\end{array}$ & the Negro & Lives & $\begin{array}{l}\text { on a lonely island of } \\
\text { poverty in the midst of } \\
\text { a vast ocean of } \\
\text { material prosperity }\end{array}$ \\
\hline Cir: Loc: Temporal & Behaver & Pro: Behavioral & Cir: Loc: Spatial \\
\hline
\end{tabular}

The word "Lives" belongs to behavioral process since the word focus on how the participant behave, and it also has one participant, namely The Negro (Behaver)

\section{Data 6}

\begin{tabular}{|l|l|l|l|}
\hline That & there are & insufficient funds & $\begin{array}{l}\text { in the great vaults of } \\
\text { opportunity of this nation }\end{array}$ \\
\hline & Pro: Existential & Existent & Cir: Loc: Temporal \\
\hline
\end{tabular}

The word "there are" belongs to existential process which is known by the word "there" and the word represent that something exist and it also has one participant namely insufficient funds (existent).

\section{The sermon of the mount by Jesus of Nazareth}

\section{Data 7}

\begin{tabular}{|l|l|l|}
\hline Lay not up & for yourselves treasures & upon earth \\
\hline Pro: Material & Goal & Cir: Location \\
\hline
\end{tabular}

The word "Lay not up" is a material process since the word expresses activity that people lay not up for yourselves treasures upon earth. In data seven just found one participant namely for yourselves treasures (Goal).

\section{Data 8}




\begin{tabular}{|l|l|l|l|}
\hline And why & Behold & Thou & the mote that is in thy brother's eye \\
\hline & Pro: Mental & Senser & Phenomenon \\
\hline
\end{tabular}

The word "behold"is a mental process since the word expresses how someone perceives through him/her sense, and it also has two participants, namely thou (senser) and the mote that is in thy brother's eye (phenomenon).

\section{Data 9}

\begin{tabular}{|l|l|}
\hline For where your treasure & Is \\
\hline Token & Pro: Relational \\
\hline
\end{tabular}

The word "is" belongs to relational process since the word expresses identifying, and it also has one participants, namely for where your treasure (Token).

\section{Data 10}

\begin{tabular}{|l|l|l|}
\hline For with what judgment & Ye & Judge \\
\hline Verbiage & Sayer & Pro: Verbal \\
\hline
\end{tabular}

The word "judge" is a verbal process since the word symbolically signaling that someone is giving the opinion or estimate with other people and it also has two participants, namely ye (sayer) and For with what judgment (verbiage).

\section{Data 10}

\begin{tabular}{|l|l|l|}
\hline And & Ye & shall find \\
\hline & Behaver & Pro: Behavioral \\
\hline
\end{tabular}

The word "shall find"is a behavioral process since the word focus on how the participant behave which namely ye (Bahever).

\section{Data 11}

\begin{tabular}{|l|l|l|l|}
\hline Or & what man & is there & of you \\
\hline & Existent & Pro: Existential & \\
\hline
\end{tabular}

The word "is there" belongs to existential process since the word represent that something exists, and it also has one participant, namely what man (Existent).

\section{The Song Entitled You Raise Me Up by Josh Groban}

Data 12

\begin{tabular}{|l|l|l|}
\hline Until & You & Come \\
\hline & Actor & Pro: Material \\
\hline
\end{tabular}


The word "come" belongs to material process since the word expresses activity that someone comes and it also has one participant, namely you (actor).

\section{Data 13}

\begin{tabular}{|l|l|l|l|}
\hline And & my heart & Burdened & Be \\
\hline & Senser & Pro: Mental & Phenomenon \\
\hline
\end{tabular}

The word "burdened" belongs to mental process since the word expresses how someone feel burdened in her/his heart and it also has two participants, namely my heart (Senser) and be (Phenomenon).

\section{Data 14}

\begin{tabular}{|l|l|l|l|}
\hline When & I & Am & Down \\
\hline & Carrier & Pro: Relational & Attribute \\
\hline
\end{tabular}

The word "am" belongs to relational process since the word expresses attributive, and it also has two participants, namely $I$ (Carrier) and down (Attribute). The list of the total number of processes in different spoken discourses is presented in table 3.1.

Table 3.1 Types of Processes in Transitivity System in different Spoken Discourses

\begin{tabular}{|c|c|c|c|c|c|c|c|}
\hline \multirow[t]{2}{*}{ No } & \multirow{2}{*}{ Types of process } & \multicolumn{2}{|c|}{ Speech } & \multicolumn{2}{|c|}{ Sermon } & \multicolumn{2}{|c|}{ Song } \\
\hline & & Freq & Per & Freq & Per & Freq & Per \\
\hline 1. & Material & 60 & $43 \%$ & 44 & $57,8 \%$ & 25 & $59,6 \%$ \\
\hline 2. & Mental & 12 & $8,5 \%$ & 9 & $12 \%$ & 1 & $2,3 \%$ \\
\hline 3. & Relational & 48 & $34,2 \%$ & 4 & $5,2 \%$ & 16 & $38,1 \%$ \\
\hline 4. & Verbal & 6 & $4,2 \%$ & 12 & $15,8 \%$ & - & \\
\hline 5. & Behavioral & 10 & $7,1 \%$ & 3 & $4 \%$ & - & \\
\hline 6. & Existential & 4 & $3 \%$ & 4 & $5,2 \%$ & - & \\
\hline & Total & 140 & $100 \%$ & 76 & $100 \%$ & 42 & $100 \%$ \\
\hline
\end{tabular}

The Reasons of Using Types of Processes in Transitivity System in different Spoken Discourses

According to Halliday (2008) transitivity system is composed of six processes that represent human experience in terms of: physical and physiological actions (Material and Behavioral), thinking and speaking actions (Mental and Verbal) and actions that signal the existence of something/someone and their identifying features (Existential and Relational). 
The examples of the data about the reasons of using the types of processes in transitivity system which were used in different spoken discourses can be seen as follows:

The speech entitled I Have a Dream by Martin Luther King and Sermon of the mount by Jesus of Nazareth.

\section{Physical actions.}

\section{Data 15}

Signed

Pro: Material

$\frac{\text { The Emancipation Proclamation }}{\text { Goal }}$

This data belongs to physical actions because the word "signed" related to the real action done by the participant one call the actor since the word express activity that people signed the emancipation proclamation. In the speech entitled I Have a Dream by Martin Luther King, material process found as the most dominant process, it is because the speech indicates the activities or events and physical action about the historical background of the hatred and racial discrimination from which the Negro people had been suffering, the demand and the reasons for a struggle of justice.

\section{Actions their identifying features.}

\section{Data 16}

This note

Token

was

Pro: Relational

$\underline{\text { a promise }}$

value

This data belongs to actions their identifying features because the verb "was" expresses identifying of "this note" as participants I and "a promise" as participant II. In the speech entitled I Have a Dream by Martin Luther King, relational process became the second dominant process, it is because the speech assigns a quality of someone feeling, and states of having their dreams.

\section{Thinking actions.}

Data 17

Who are asking the devotees of civil rights

Senser Pro: Mental Phenomenon

This data belongs to thinking actions because the verb "are asking" described as states of thinking or psychological events. In the speech entitled I Have a Dream by Martin Luther King, mental process became the third dominant process. 
Physiological actions.

Data 18

$\begin{array}{llll}\frac{\text { that my four little will }}{\text { children }} & \text { one day } & \frac{\text { live }}{\text { Pro: }} & \underline{\text { in a nation }} \\ \text { Behaver } & \text { Cir: Spatial Temporal } & \text { Behavioral } & \end{array}$

This data belongs to physiological actions because the verb "live" represents human experience in terms of physiological actions. In the speech entitled I Have a Dream by Martin Luther King, behavioral process became the fourth dominant process.

Speaking actions.

Data 19

$\frac{\text { I }}{\text { Sayer }} \quad \frac{\text { must say }}{\text { Pro: Verbal }} \quad \frac{\text { to my people }}{\text { Receive }}$

This data belongs tospeaking actions because the verb "must say" shown activities related to speaking. In the speech entitled I Have a Dream by Martin Luther King, verbal process became the fifth dominant process.

Actions that signal the existence of something/someone.

Data 20

there is an invigorating autumn of freedom and equality

Pro: Existential Existent

This data belongs to actions that signal the existence of something/someone because the verb "there is" represented that something exists or happens.In the speech entitled I Have a Dream by Martin Luther King, existential process became the sixth dominant process.

\section{The Song Entitled You Raise Me Up by Josh Groban}

Physical actions.

Data 21

$\frac{\text { You }}{\text { Actor }} \quad \frac{\text { raise }}{\text { Pro: }}$ Material $\quad \frac{\text { me }}{\text { goal }} \underline{\text { up }}$

This data belongs to physical actions because the verb "raise" related to the real action done or physical by the participant one called the actor and participant two called goal, in the Song Entitled You Raise Me Up by Josh Groban, material 
process also became the most dominant process. It is because the topic is about how God made to the people who strength through the faith.

\section{Actions their identifying features.}

Data 22

when

$\underline{\text { T }}$ Token

$\underline{\mathbf{a m}}$

on your shoulders

Pro: Relational

Cir: Loc: Spatial

This data belongs to actions their identifying features because the verb "am" expresses identifying. The reasons of using Relational process are to construes being and relation among entities through attribution, identification and possession.In theSong Entitled You Raise Me Up by Josh Groban, relational process became the second dominant process, it is because the song assigns a quality of someone feeling and conveys a strong theme in God.

\section{Thinking actions.}

Data 23

and

$\begin{array}{lll}\text { my heart } & \text { burdened } & \text { Be } \\ \text { Senser } & \text { Pro: Mental } & \text { Phenomenon }\end{array}$

This data belongs to thinking actions because the verb "burdened" described as states of thinking. IntheSong Entitled You Raise Me Up by Josh Groban, mental process became the least dominant process.

The result of the reasons of using types of processes in transitivity system which were used in different spoken discourses will be display in table 4.2

Table 4.2. The Reasons of Using Types of Processes in Transitivity System in Different Spoken Discourses

\begin{tabular}{|l|l|c|c|c|c|c|c|}
\hline \multirow{2}{*}{ No. } & \multicolumn{1}{|c|}{ Spoken discourses } & \multicolumn{2}{c|}{ Speech } & \multicolumn{2}{c|}{ Sermon } & \multicolumn{2}{c|}{ Song } \\
\cline { 3 - 8 } & The reasons & Freq & Rank & Freq & Rank & Freq & Rank \\
\hline 1. & Physical actions & 60 & 1 & 44 & 1 & 25 & 1 \\
\hline 2. & Thinking & 12 & 3 & 9 & 3 & 1 & 3 \\
\hline 3. & Identifying features & 48 & 2 & 4 & 4 & 16 & 2 \\
\hline 4. & Speaking actions & 6 & 5 & 12 & 2 & - & \\
\hline 5. & Physiological action & 10 & 4 & 3 & 6 & - & \\
\hline 6. & $\begin{array}{l}\text { Actions that signal the } \\
\text { existence of someone } \\
\text { /something }\end{array}$ & 4 & 6 & 4 & 5 & - & \\
\hline \multicolumn{2}{|l|}{} & 140 & & 76 & & 42 & \\
\hline
\end{tabular}


Based on the table above, it is shown that in the all of the spoken discourses namely the speech entitled I Have a Dream by Martin Luther King, the sermon of the mount by Jesus of Nazareth, and the song entitled You Raise Me Up by Josh Groban, Material processes are found to be the most dominant, the reasons because all of the spoken discourses indicates events and activities that happen in the outside world of human beings. The result of data analysis in table 4.2.2, shown that spoken discourses factor seem influence the use of the types of processes in transitivity system, it shown that all of the speakers use the same number of material process, mental process and almost all of the ranks of using the types of processes were same.

\section{Discussion}

There are six types of processes in transitivity system were found in the speech entitled I have a dream by Martin Luther King in 1963, namely: (1) material process, (2) mental process, (3) relational process, (4) verbal process, (5) behavioral process, (6) existential process. It contents $60(43 \%)$ material processes, $12(8,5 \%)$ mental processes, $48(34,2 \%)$ relational processes, $6(4,2 \%)$ verbal processes, $10(7,1 \%)$ behavioral processes, $4(3 \%)$ existential processes. In the sermon of the mount by Jesus of Nazareth which published in 2012, there are also 6 (six) types of processes in transitivity system found, namely: (1) material process, (2) mental process, (3) relational process, (4) verbal process, (5) behavioral process, (6) existential process. It contents $44(57,8 \%)$ material processes, $9(12 \%)$ mental processes, $4(5,2 \%)$ relational processes, $12(15,8 \%)$ verbal processes, $3(4 \%)$ behavioral processes, $4(5,2 \%)$ existential processes.

In the song entitled You Raise Me Up by Josh Groban in 2003, there are not all of the types of transitivity system found because the songhas lyric limitation, andthere isrepetition of wordsinthe song. And just 3 (three) types of processes in transitivity system found. They are: (1) material process, (2) mental process, (3) relational process. It contents $25(59,6 \%)$ material processes, $1(2,3 \%)$ mental process, $16(38,1 \%)$ relational processes.

There are 6 reasons of using types of processes in transitivity system in different spoken discourses, namely; 1) physical actions, 2) thinking actions 3) identifying features 4) speaking actions 5) physiological actions 6) actions that signal the existence of something/someone. In this study, it was figured out that in the speech entitled I have a dream by Martin Luther King in 1963 were 60 examples of physical actions, 12 examples of thinking actions, 48examples of identifying features, 6 examples of speaking actions, 
10examples of physiological actions, 4examples ofactions that signal the existence of something/someone. In the sermon of the mount by Jesus of Nazareth which published in 2012 were 44examples of physical actions, 9examples ofthinking actions, 4examples ofidentifying features, 12examples ofspeaking actions, 3examples ofphysiological actions, and 4examples ofactions that signal the existence of something/someone. In the song entitled You Raise Me Up by Josh Groban in 2003 were 25examples of physical actions, 1examples of thinking actions, 16examples of identifying features.

This study related to Halliday (2008) stated that transitivity system is composed of six processes that represent human experience in terms of: physical and physiological actions (Material and Behavioral), thinking and speaking actions (Mental and Verbal) and actions that signal the existence of something/someone and their identifying features (Existential and Relational).

\section{References}

Halliday, M.A.K. (2008).An introduction to functional grammar (3rd Ed.). London: Edward Arnold.

Harwiyati, R. (2016). Transitivity System on Joko Widodo's Speech at the APEC CEO Summit on November $10^{\text {th }}, 2014$, in Beijing, China. Premise Journal. $5(1), 161-171$.

Hemas, S.M., and Ariyanti, L. (2016). Transitivity and Ideology in Emma Watson's Speech for the Heforshe Campain (Critical Discourse Ananlysis). Language Horizon, 1(1), 27-37.

Saragih, A. (2006).Introducing Systemic Functional Grammar. Medan: FBS UNIMED (Unpublished).

.(2010).Discourse Analysis: A Systemic Functional Approach: The Analysis of Texts. Medan: FBS UNIMED (Unpublished). 